\title{
Historein
}

Vol 13 (2013)

Questions and Orientations in History during the last 20 years. Part 2

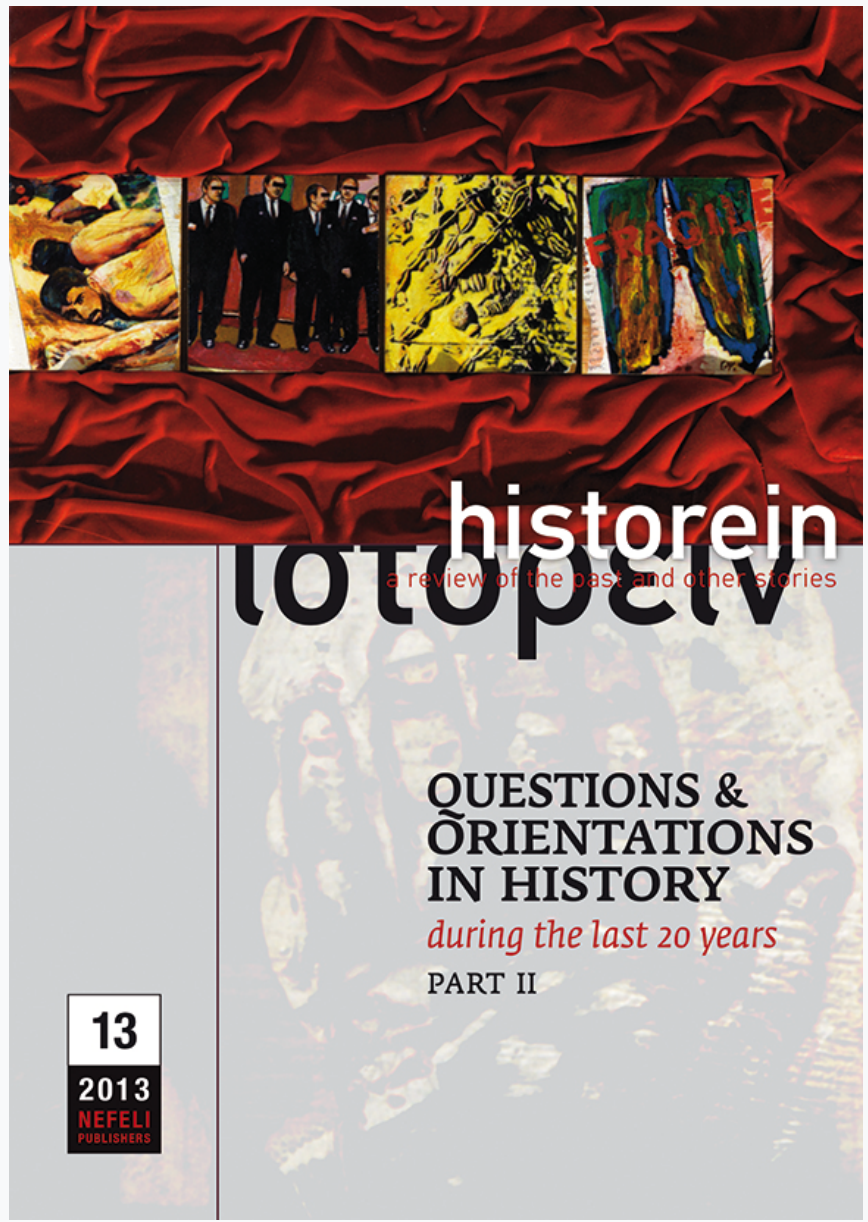

\section{Postcolonial criticism encounters late Ottoman studies}

Vangelis Kechriotis

doi: $\underline{10.12681 / \text { historein.183 }}$

Copyright @ 2014, Vangelis Kechriotis

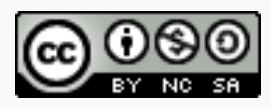

This work is licensed under a Creative Commons Attribution-NonCommercialShareAlike 4.0.

To cite this article:

Kechriotis, V. (2013). Postcolonial criticism encounters late Ottoman studies. Historein, 13, 39-46.

https://doi.org/10.12681/historein.183 
In Ottoman studies, it is only in the last decade that colonialism has been considered a useful analytical category. This may be partly due to the fact that, in the 1970s and 80s, especially in approaches which drew on the dependency theory and the integration of the Ottoman Empire into the world economy, the latter was studied as one of those regions which was never effectively colonised.' However, recently postcolonial studies have attracted the interest of nineteenth-century historians who have reversed the argument and tend to include the Ottoman Empire not among the states that were subject to colonisation but among the colonisers. The aim of this paper is to critically approach the recent literature that one way or another utilises terminology and narratives that derive from the area of postcolonial studies. It also aspires to suggest an alternative way of engaging with the condition of colonisation, by drawing on religious divisions. Specifically it looks at Christians, and more particularly Greek Orthodox, as potentially colonised populations or agents of colonisation, respectively.

As Selim Deringil has put it, in one of the seminal studies in this respect, "sometime in the nineteenth century the Ottoman elite adopted the mindset of their enemies, the arch-imperialists and came to conceive of its periphery as a colonial setting". ' Building on Albert Hourani's depiction of the Ottomans as the "Romans of the Muslim world", ${ }^{3}$ Deringil introduces the term "borrowed colonialism", a term firstly used in the Russian context to describe a phenomenon which developed in parallel with European colonialism. ${ }^{4}$ In his view, within this context colonialism was a "survival tactic" and, therefore, the Ottoman Empire is very different from "the aggressive industrial empires of the West". In oth-

\section{Postcolonial}

criticism encounters

late Ottoman

studies

Vangelis Kechriotis

Boğaziçi University, Istanbul 
er words, he claims that the Ottomans were fully aware that they had to qualify as a colonial power if they were not to end up as a colony themselves.

Reflecting on why the Ottoman phenomenon had not been studied within this context, Deringil claims that the history of the Ottoman Empire was "perched" between western historiography, on the one hand, and the study of the "Muslims/Middle Easterners who matter" (i.e. Arabs, Jews, Iranians, Indians), on the other. He criticises subaltern studies, therefore, for being preoccupied with the "evils of colonialism" and ignoring a "major non-western sovereign state whose destinies were in many ways intertwined with the destinies of India". ${ }^{5}$ Moreover, he attributes the abovementioned ignorance to non-western historians who tend to be eurocentric along with the long-standing practice of European historians to ignore the historiography of the third world, which Dipesh Chakrabarty has described as the "inequality of ignorance". ${ }^{6}$ As the Bengali historian put it more bluntly recently, if Europe is a universal paradigm for modernity, we are all, European and non-European, to a degree inescapably Eurocentric.?

It is clear that Deringil is not engaging in an overall critical re-evaluation with regard to postcolonial studies. It is not my purpose to do that here, either. It is actually quite interesting that such a debate appeared in the field of Ottoman studies when the paradigm itself had lost its momentum and was definitely less appealing than before. However, this might be exactly one of the reasons for such an engagement. The criticism of postcolonial studies followed extreme and mutually contradicting paths. On the one hand, historians in various fields were accused of trying to implement the relevant paradigm on apparently any historical period, such as colonialism in ancient Rome or early modern Venice. On the other hand, critics argued that postcolonial historians were so obsessed with the particular period and geography that they were unable to properly historicise the phenomenon and connect to similar experiences in other geographies. As I have mentioned, Deringil belongs to the second category. The real issue, however, for our purposes, is not whether the storm of criticism would compel postcolonial historians to adopt a broader perspective, but why and under what circumstances the Ottoman Empire can or should be compared with other empires. I will return to this point later.

Deringil refers to Ussama Makdisi's 2000 study which "situates the Tanzimat reform process and reactions to it in the subaltern discourse" as the first attempt to introduce the Ottoman Empire to this historiographical debate. ${ }^{8}$ Makdisi's ideas, though, follow a different trajectory. He sets out from the deconstruction of the "decline" thesis in recent literature in order to argue that Ottomanists, in their effort to shed light on the complex Ottoman phenomenon, have paid little attention to a notion of Ottoman imperialism which he relates to the empire's bid to become a modern nationstate. ${ }^{9}$ He uses, of course, an example that is rather "too obvious" in order to prove his claim, that of the Arab lands, which are described as "backward, primitive and savage and which 'constituted' metaphorical spaces in which Istanbul-centred reformers elaborated a notion of what Ottoman modernity was, i.e. rational, scientific and civilised". ${ }^{10}$

More recently, in 2005, Makdisi addressed the same configuration of power from the vantage point of cultural analysis, building on the debate on Orientalism and articulating his own perception of what he calls "Ottoman Orientalism", namely a complex of Ottoman attitudes produced 
by the nineteenth-century age of Ottoman reform that acknowledged the west as the home of progress and the east the site of backwardness. He, himself, pays his tribute to Deringil and his conceptualisation of "borrowed colonialism" and points out the fact that "through efforts to study, discipline, and improve imperial subjects, Ottoman reform created a notion of the pre-modern within the empire in a manner akin to the way European colonial administrators represented their colonial subjects". ${ }^{117}$ But then, he adds that this process contributed to the formation of a modern Ottoman Turkish nation that had to lead the other "stagnant ethnic and national groups" into an Ottoman modernity. One wonders whether these stagnant groups could be anything other than the Arabs, or even than the Muslims in general, to begin with? Moreover, the assumption that this version of Orientalism led to the articulation of a Turkish national identity seems too far-fetched. I will return to that too.

Let me address here the issue of terminology. There are so many terms that suddenly appeared to attract our attention. Apart from "Ottoman Orientalism", we also have "Orientalism alla turca"," as it appears in Christoph Herzog and Raoul Motika's "Orientalism Alla Turca: Late 19th/Early 20th century Ottoman voyages into the Muslim "outback"; the "Ottoman civilising mission" in Christoph Herzog's "Nineteenth-century Baghdad through Ottoman eyes";'12 the "Ottoman man's burden"13 and "modern Ottoman imperialism", again in Makdisi; ;4 Deringil's terms of "borrowed colonialism" and the "Ottoman colonial project"; and "colonial Ottomanism", ${ }^{15}$ used by Thomas Kühn to describe the same phenomenon in his study on Yemen.

This terminological inflation, ${ }^{16}$ apart from obstructing methodological clarity, denotes also different historiographical agendas. Certainly, the motivations of these historians are not the same, nor do they all subscribe to the postcolonial criticism as such. While Deringil intends to place the Ottoman Empire on a par with the major European colonial empires of the era, claiming in scholarship what the Ottomans themselves never managed to achieve in politics, Makdisi seems to address the same issue from the point of view of the alleged subaltern, building on an old-fashioned perception of the Tanzimat centre-periphery debate and an understanding of the Turkish nature of the Ottoman bureaucracy which reiterates similar perceptions inherited from Arab nationalism. Motika and Hertzog, on the other hand, seem to critically address but also at the same time reorientalise what they see as a peculiar fashion of Orientalism, whereas Kühn, historiographically speaking, sticks to a safer example, that of Yemen, since that was the only real Ottoman colony, sensu stricto, in the second half of the nineteenth century, a territory whose conquest was justified on the grounds of protecting the Islamic world against the imperialist west, but which, in the end, was invested with the narrative of a civilising mission very similar to the western ones. Based on the study of the conundrum that Yemen presented for Ottoman bureaucrats, he argues that the Tanzimat reformers and their descendents elaborated a form of governance based on "the formalisation and reproduction of perceived difference". ${ }^{17}$

This multiplicity of approaches is indicative of the fact that postcolonial criticism has inspired late Ottomanists in various ways. Nevertheless, a younger generation of Ottomanist historians, such as Özgür Türesay, has argued that postcolonial criticism should be dismissed as irrelevant to the study of what this historian describes as a gentilhomme attitude, an outcome of elite training and urban culture, on the part of Ottoman officials towards the populations of the periphery. ${ }^{18}$ Others go 
even further and dismiss any attempt to compare the Ottoman Empire with other empires. What I find problematic here is the regressive attitude, firmly grounded on a notion of Ottoman exceptionalism, which is politically and historiographically untimely, and which proves in return why a failed comparison is preferable to self-referential arguments. In a special issue of the Comparative Studies of South Asia, Africa and the Middle East journal, edited by Dina Khoury and Dane Kennedy, the two empires, the Ottoman and the British, are systematically compared. In their introduction, "Comparing empires: The Ottoman domains and the British Raj in the long nineteenth century", the editors point out that their purpose involved "shifting the study of empires from narratives that differentiate European from non-European variants to those that examine their shared characteristics ... providing a fuller appreciation of the shared cultural challenges they confronted and the connective issues that bound them together". ${ }^{19}$ Among the volume's interesting articles, the most typical example for our purpose is offered by Thomas Kühn, whom I mentioned earlier.

Actually, the Ottoman Empire has been placed in comparative perspective in the past in different historiographical contexts with respect to the continental empires. Such an endeavour was first carried out in the context of the paradigm of integration into the world economy, and Ottomanist historians, whose work focused mostly on the economy, became internationally renowned through the pages of the Review journal, published by the Fernand Braudel Centre at Binghamton. ${ }^{20}$ More recently, a younger generation of scholars that also focuses on politics and culture reiterated this comparative approach. ${ }^{21}$ Another thread of comparison was initiated by the fall of the communist regimes and the re-emergence of empire as a model that was no longer regarded as politically illegitimate and academically marginal. ${ }^{22}$ The revived interest in empire has been described as the "imperial turn". ${ }^{23}$ In more recent works, comparison seems to be taking root in the academic production on the Ottoman Empire, at least in the US. ${ }^{24}$

In this last part, I would like to focus on a particular aspect of this debate. Deringil has already described the "premodern" Turkish/Islamic tradition of the Ottoman Empire prior to the Tanzimat and the "modern" enlightenment practices which it introduced as two halves of the Ottoman colonial project which were not hermeneutically sealed off from one another. In his view, what makes Ottoman "borrowed colonialism" interesting is the fact that "the Ottoman modernity project was the result of historical processes and trends which were already taking place in the eighteenth century". ${ }^{25}$ There is, however, one particular issue related to Deringil's analysis that I would like to address. He portrays the particularity of the "Ottoman version of colonialism" as related to the commonality of religion, since his study focuses on a condition where the ruler and the ruled are of the same religion, namely Islam. This precondition is important in the attempt to understand how this version diverges from the western Christian ruler-non-Christian-ruled version. However, and if we disregard the importance of the confessional divide that for the Hamidian era plays a major role, one wonders whether it would be of any use to study, within "the Ottoman version of colonialism", cases where the roles of the western version have been reversed, namely where the ruled was a non-Muslim and the ruler a Muslim. In this discussion, there is the implicit assumption that culture, which in this era took the form of a modern reconfiguration of religion, as conceptualised by Gellner, ${ }^{26}$ was an important denominator in shaping collectivities on both sides of the political bipolar divide. In other words, social attitudes or ethnic divisions can be based on the grounds of religious or, occasionally, confessional affiliation. 
If we accept that this assumption is valid, what did it mean for a Christian to be subordinate to a Muslim, in terms of colonial domination? I find this to be a legitimate question. At the same time, one should not disregard the slippery ground on which such a discussion is carried out. For the simple reason that if we are to place the Ottoman Empire in a comparative perspective with the rest of the historically more recent empires, such as the British one, we should be ready to carry the argument to its logical conclusion, namely the recognition that Ottoman rule was a form of "foreign domination". However, even if, in many areas, there was a clear divide between the local popular culture and the administrative elite, such a conclusion would be difficult to substantiate. One has to bear in mind that we are referring to nineteenth-century colonial experience and not to fifteenthcentury territorial expansion. In other words, we cannot project the notion of "foreign domination", which certainly resonates with the notion of "illegitimate rule", as this is defined by nineteenth-century nationalist narratives, back to the premodern era; otherwise, we would be reiterating the ethnocentric perspective of national historiographies. Makdisi has been accused of doing exactly this, as he assumes that Ottoman rule in the Arab lands always had the attributes of colonial rule. He thus forges a clear modern divide for the nineteenth century, projecting it back to a premodern era.

Nevertheless, even if we do not essentialise either Ottoman rule or the distinction between Muslims and non-Muslims, the issue still remains. Could the debate on Ottoman colonialism and its cultural component, Ottoman Orientalism, be meaningful for studies related to power structures involving both religious groups? Makdisi, despite his Arabocentric perspective, hints at an answer by arguing that the empire's commonality with the Muslim majority "was implicitly and explicitly framed within a civilisational and temporal discourse that ultimately justified Ottoman Turkish rule over Muslim and non-Muslim subjects, over Arabs, Armenians, Kurds, Bulgarians, etc". ${ }^{27}$

More recently, Ebru Boyar in her own work has focused on Ottoman and Turkish perceptions of the Balkans. ${ }^{28}$ In her chapter "The Balkan people and the Balkan states", she discusses Ottoman condescension towards the petty Balkan states, which is reminiscent of Ottoman colonial attitudes in the Arab periphery. Persistent references to the Serbs as "pig farmers", for instance, are commensurate with the dominant, late-nineteenth-century European discourse that viewed the Balkan peoples, to borrow Ipek Yosmaoğlu's words, "as noble savages at best and corrupt slaves at worst, but also the ways in which this discourse penetrated the Balkan peoples' (and, evidently, the Ottomans') own formulations of a sliding scale of nations". ${ }^{29}$ Could, however, condescension and contempt in this context be equated with European colonial attitudes?

There is a second issue, though, that concerns the presence of the other empires within the territory of the Ottoman Empire: the capitulations, which were used in order to protect many non-Muslim Ottoman subjects as well. From as early as the seventeenth century, through the granting of concessions to foreign powers in the form of bilateral agreements (ahdname) or documents of exemption (berat) provided to individuals, many enjoyed the status of extra-territoriality. As the Ottoman Empire lost ground in the international power balance, such agreements were used as a pretext for straightforward intervention in Ottoman domestic affairs. As a result, the subject non-Muslims, through profiting from the presence of other colonial powers, managed to partially avoid being monitored by the Ottoman authorities. This describes a picture where the ruler and the ruled, the coloniser and the colonised, the dominant and the subaltern, were continuously changing roles. 
Contrary to conventional wisdom, it seems that in the final decades of the Ottoman Empire a certain group from among the Christian, mostly middle-class elites (Greek Orthodox, Armenian or Assyrian) had their own vision of Ottoman society which was not necessarily inspired by a nationalist or separatist passion. Instead, they had developed their own version of a mission civilisatrice which, in their eyes, was justified by their superior economic and cultural status compared to the Muslim population and, even, the Muslim elite. Such attitudes contributed to the tension and antagonism between ethnically distinct elites, who soon abandoned the option of an all-encompassing Ottoman middle class that would lead the way to modernisation, and they took it upon themselves, each one separately, to justify their leading role in this process. The question that needs to be addressed is how fruitful would it be to extend the controversial debate on the colonial overtones of the ruling elites in the Tanzimat and post-Tanzimat era, as introduced by Deringli, Makdisi and others, to a different era, that of the post- 1908 constitutional regime, which was politically dominated by a very different kind of bureaucratic and military personnel, who themselves wished to break from what they saw as the failed policies of the Tanzimat.

As I have argued elsewhere, this was the era when a large part of the Muslim and non-Muslim population, could, for the first time, enjoy the privilege of aspiring for a better future for themselves and their families. "Middle class" values were endorsed by many who, while hoping for personal social improvement, at the same time sought to take over the control of the lower classes, either from the state or from the upper class, and thus establish a new hegemony which can be attributed with the quality of "internal colonialism" ${ }^{30}$ In the context of ethnic rivalry and political instability, the above concerns acquired a very different dimension. ${ }^{31}$ Notions such as progress, order and proper behaviour became the values not of a "middle class" but of a "Turkish-Muslim middle class" or a "Greek Orthodox middle class" - with different claims to Ottomanness to be sure - but with the fear that if a rival claim to Ottomanness should prevail, first and foremost the one promoted by the Young Turks, all other alternatives would perish. ${ }^{32}$ That's why the respective discourses became sharper, more aggressive and, occasionally, even adopted a colonial mentality. This should not come as a surprise. Apart from colonial models being much more available now than what was the case during the Tanzimat era, the Young Turks, despite their internal divisions, were inspired, as Şükru Hanioğlu has aptly shown, ${ }^{33}$ by ideas drawing on positivism and social engineering more than anything else.

The recent proliferation within late Ottoman studies of works that utilise terminology and concepts that were first introduced by postcolonial literature certainly cannot be a coincidence. On the one hand, it reveals an attempt to integrate the study of the Ottoman Empire into the broader "imperial turn" that has emerged in recent years. On the other, it paves the ground for a revisionist approach that aims not necessarily at delegitimising Ottoman rule but definitely at establishing a stricter division between the local population and the administrative elite. It is important to remember that a comparison with the British or French empires is not the only possible option, though. In fact, the Ottoman Empire has been already studied in the context of continental empires. Moreover, the way Arabs, Armenians or Greek Orthodox could be integrated into the Ottoman elites does not resemble the Algerian or Raj cases. After all, one could attribute the recent choice to compare the Ottoman with the British Empire to a historiographical strategy that aims at conveniently situating 
Ottoman studies in Anglo-Saxon academia. However, I argue that, even if postcolonial criticism cannot be uncritically applied to late Ottoman studies, the main focus of its agenda, namely the way that history and culture are utilised in politics in order to forge patterns of hierarchy, can benefit the study of power structures across diverse ethnic or religious boundaries.

\section{NOTES}

1 Şevket Pamuk, "The Ottoman empire in comparative perspective", Review 11/2 (1988), 127-150, 132-133.

2 Selim Deringil, "They live in a state of nomadism and savagery': the late Ottoman empire and the postcolonial debate", Society for Comparative Study of Society and History 45 (2003), 311-342, 311.

3 Deringil refers to Albert Hourani, “How should we write the history of the Middle East?", International Journal of Middle Eastern Studies 23 (1991), 125-36.

4 Deringil, "They live in a state," 312.

$5 \quad$ Ibid, 314.

6 Dipesh Chakrabatry, "Postcoloniality and the artifice of history: who speaks for 'Indian' pasts?", Representations 37 (1992), 1-26. Chakrabatry refers to Satish Saberwall who, while referring to Europe, studies basically western Christianity. Satish Saberwall, "On the making of Europe: reflections from Delhi", History Workshop Journal 33 (1992), 145-51.

7 Dipesh Chakrabatry, Provincialising Europe: Postcolonial Thought and Historical Difference, Princeton University Press, Princeton 2000.

8 Deringil refers to Ussama Makdisi, "Corrupting the sublime sultanate: the revolt of Tanyus Shahin in 19th-century Ottoman Lebanon', Comparative Studies in Society and History 42 (2000), 180-208.

9 Ussama Makdisi, "Rethinking Ottoman imperialism: modernity, violence and the cultural logic of Ottoman reform", in Jens Hanssen, Thomas Philipp and Stefan Weber (eds), The Empire in the City: Arab Provincial Cities in the Ottoman Empire, Würzburg: Ergon Verlag, 2002, 29-48, 29.

10 Ibid, 30.

11 Ussama Makdisi, “Ottoman Orientalism”, American Historical Review 107/3 (2002), 768-796.

12 Christoph Herzog and Raoul Motika, "Orientalism 'Alla Turca': late 19th/early 20th-Century Ottoman voyages into the Muslim 'outback', Die Welt des Islams 40/2 (2000), 139-195.

13 Christoph Herzog, "Nineteenth-century Baghdad through Ottoman eyes", in Hanssen, Philipp and Weber (eds), The Empire in the City, 311-328. In the same volume, see Thomas Kühn, "Ordering urban space in Ottoman Yemen, 1872-1914", 329-348, 336.

14 Makdisi “Ottoman Orientalism", 782.

15 Makdisi, "Rethinking Ottoman imperialism," 30.

16 Thomas Kühn, "Shaping and reshaping colonial Ottomanism: contesting boundaries of difference and integration in Ottoman Yemen", Comparative Studies of South Asia, Africa and the Middle East 27/2 (2007), 315-331, 318.

17 I am indebted to my colleague Özgür Türesay, who first pinpointed to these terminological varieties in "Le 'colonialisme ottoman': réflexions sur une tournure historiographique récente," a paper presented at the workshop L'Orientalisme désorienté? La Turquie contemporaine au miroir des approches postcoloniales, Rennes Institute of Political Studies, 28-29 Jan 2010. 
18 Kühn, "Shaping and reshaping colonial Ottomanism".

19 Türesay, "Le 'colonialisme ottoman'".

20 Dina Khoury and Dane Keith Kennedy, "Comparing empires: the Ottoman domains and the British raj in the long nineteenth century", Comparative Studies of South Asia, Africa and the Middle East 27/2 (2007), 233-244. By the way, such a comparison has already been pursued in the past in different contexts. See for instance Dominique Lieven, Empire: The Russian Empire and its Rivals, New Haven: Yale University Press, 2001, and Huri Islamoğlu-Inan, "Oriental despotism in world system perspective", in Huri Islamoğlu-Inan (ed.), The Ottoman Empire and the World Economy, Cambridge: Cambridge University Press, 2004, 1-24.

21 Pamuk, "The Ottoman empire in comparative perspective", 127-150; Reşat Kasaba, "Treaties and friendships: British imperialism, the Ottoman empire, and China in the nineteenth century", Journal of World History 4/2 (1993), 215-241.

22 Michael A Reynolds, Shattering Empires: The Clash and Collapse of the Ottoman and Russian Empires, 1908-1918, Cambridge: Cambridge University Press, 2011; Alison Frank, "The children of the desert and the laws of the sea: Austria, Great Britain, the Ottoman empire, and the Mediterranean slave trade in the nineteenth century," American Historical Review 117/2 (2012), 410-444.

23 Karen Barkey and Mark von Hagen (eds), After Empire: Multiethnic Societies and Nation-Building; The Soviet Union and the Russian, Ottoman, and Habsburg Empires, Boulder: Westview Press, 1997.

24 Alan Mikhail and Christine M. Philliou, "The Ottoman empire and the imperial turn", Comparative Studies in Society and History 54/4 (2012), 721-745. The term has been used earlier with regard to other empires, such as the Russian. See Michael David-Fox, Peter Holquist and Alexander M. Martin, "The imperial turn", Kritika 7, (2006), 505-712.

25 Karen Barkey, Empire of Difference: The Ottomans in Comparative Perspective, Cambridge: Cambridge University Press, 2008. Silvia Nagy-Zekmi and Chantal Zabus (eds), Colonization or Globalization?: Postcolonial Explorations of Imperial Expansion, Lanham: Lexington Books, 2010.

26 Deringil, "State of nomadism", 316.

27 Ernest Gellner, Nations and Nationalism, Oxford: Blackwell, 1983.

28 Makdisi, "Ottoman Orientalism", 769.

29 Ebru Boyar, Ottomans, Turks and the Balkans: Empire Lost, Relations Altered, London: Tauris, 2007.

30 Ipek K. Yosmaoglu. Review of Ebru Boyar, Ottomans, Turks and the Balkans: Empire Lost, Relations Altered, H-Turk, H-Net Reviews. March 2010, www.h-net.org/reviews/showrev.php?id=29845 (accessed 19 May 2013).

31 Michael Hechter, Internal Colonialism, Berkeley: University of California Press, 1975.

32 I owe many of these ideas to the discussions at the Bourgeois Seas Symposium, Florence, 19-20 Sept 2008.

33 Vangelis Kechriotis, "Civilization and order: middle-class morality among the Greek-Orthodox in Smyrna/ Izmir at the end of the Ottoman empire," in Andreas Lyberatos (ed.), Social Transformation and Mass Mobilization in the Balkan and Eastern Mediterranean Cities (1900-1923), Irakleio: Crete UP, 2013, 115-131.

34 Sükrü Hanioğlu, Preparation for Revolution: The Young Turks, 1902-1908, New York: Oxford University Press, 2001. 